medRxiv preprint doi: https://doi.org/10.1101/2022.01.03.22268706; this version posted January 5, 2022. The copyright holder for this preprint (which was not certified by peer review) is the author/funder, who has granted medRxiv a license to display the preprint in perpetuity. This article is a US Government work. It is not subject to copyright under 17 USC 105 and is also made available for use under a CCO license.

\title{
Does choice of athletic footwear affect musculoskeletal injury risk in US Coast Guard recruits? A retrospective cohort study
}

John J. Fraser, PT, DPT, PhD, FACSM ${ }^{1 *}$; email: john.j.fraser8.mil@mail.mil, ORCID: 00000001-9697-3795, Twitter: @NavyPT

Ryan Pommier, PT, DPT²; email: Ryan.Pommier@uscg.mil

Andrew J MacGregor, PhD, MPH ${ }^{1,3}$; email: andrewmacgregor@protonmail.com

Amy Silder, PhD ${ }^{1,4}$; email: amy.b.silder.ctr@mail.mil

Todd C. Sander, PT, PhD, ATC5; email: sandetod@gvsu.edu

1. Directorate for Operational Readiness \& Health, Naval Health Research Center, San Diego, CA, USA

2. Samuel J. Call Health Services Center, US Coast Guard Training Center, Cape May, NJ, USA

3. Axiom Resource Management, Inc., San Diego, CA, USA

4. Leidos, Inc., San Diego, CA, USA

5. Department of Physical Therapy and Athletic Training, Grand Valley State University, Grand Rapids, MI, USA

*Address correspondence to John J. Fraser, Directorate for Operational Readiness \& Health, Naval Health Research Center, 140 Sylvester Road, San Diego, CA 92106, USA. Tel: 757-4380390, email: john.j.fraser8.mil@mail.mil, ORCID: 0000-0001-9697-3795, Twitter: @NavyPT

Contributors: JJF contributed to study design, data analysis, and interpretation, and in drafting this manuscript. RP contributed to data collection. RP, AJM, AS, TCS contributed to data interpretation. All authors have reviewed and approved this manuscript.

The preprint of this manuscript is archived on MedRxiv at doi:10.1101/XXXXXXXXXXXX 
medRxiv preprint doi: https://doi.org/10.1101/2022.01.03.22268706; this version posted January 5, 2022. The copyright holder for this preprint

(which was not certified by peer review) is the author/funder, who has granted medRxiv a license to display the preprint in perpetuity.

This article is a US Government work. It is not subject to copyright under 17 USC 105 and is also made available for use under a CCO license.

Disclaimer: The authors are military service members or employees of the U.S. Government. This work was prepared as part their official duties. Title 17, U.S.C. $§ 105$ provides that copyright protection under this title is not available for any work of the U.S. Government. Title 17, U.S.C. $\S 101$ defines a U.S. Government work as work prepared by a military service member or employee of the U.S. Government as part of that person's official duties. The views expressed in this article are those of the authors and do not necessarily reflect the official policy or position of the Department of the Navy, Department of Defense, United States Coast Guard, Department of Homeland Security, nor the U.S. Government. The study protocol was approved by the US Coast Guard Institutional Review Board in compliance with all applicable Federal regulations governing the protection of human subjects. Research data were derived from an exempted US Coast Guard Institutional Review Board protocol. 
medRxiv preprint doi: https://doi.org/10.1101/2022.01.03.22268706; this version posted January 5, 2022. The copyright holder for this preprint

(which was not certified by peer review) is the author/funder, who has granted medRxiv a license to display the preprint in perpetuity.

This article is a US Government work. It is not subject to copyright under 17 USC 105 and is also made available for use under a CCO license.

\title{
Does choice of athletic footwear affect musculoskeletal injury risk in US Coast Guard recruits? A retrospective cohort study.
}

\begin{abstract}
Context: Musculoskeletal injuries (MSKIs) are ubiquitous during initial entry military training, with overuse injuries in the lower extremities the most frequent. A common mechanism for overuse injuries is running, an activity that is an integral part of United States Coast Guard (USCG) training and a requirement for graduation.
\end{abstract}

Objective: Assess the effects of athletic footwear choice on lower quarter MSKI risk in USCG recruits.

Design: Descriptive Epidemiological Study

Setting: USCG Training Center, Cape May, NJ

Participants: A retrospective cohort study was performed in which 1229 recruits (1038 males, 191 females) were allowed to self-select athletic footwear during training. A group of 2876 recruits (2260 males, 616 females) who trained under a policy that required obligatory wear of prescribed athletic shoes served as a control.

Main Outcome Measures: Demographic data and physical performance were derived from administrative records. Injury data were abstracted from a medical tracking database. Multivariable logistic regression was used to assess group, age, sex, height, body mass, and run times on MSKI outcomes.

Results: Ankle-foot, leg, knee and lumbopelvic-hip complex diagnoses were ubiquitous in both groups (experimental: 20.37 to 29.34 per 1000 recruits; control: 18.08 to 25.59 per 1000 
medRxiv preprint doi: https://doi.org/10.1101/2022.01.03.22268706; this version posted January 5, 2022. The copyright holder for this preprint (which was not certified by peer review) is the author/funder, who has granted medRxiv a license to display the preprint in perpetuity.

This article is a US Government work. It is not subject to copyright under 17 USC 105 and is also made available for use under a CCO license.

recruits). Group was not a significant factor for any of the injuries assessed. Sex was a significant factor in all injury types, with female recruits demonstrating $\sim 2.00$ greater odds of experiencing running-related injuries (RRIs), overuse injuries, or any MSKI in general. When considering ankle-foot or bone stress injuries, the risk in female recruits was 3.73 to 4.11 greater odds than their male counterparts. Run time was a significant predictor in RRI, all overuse injuries, and for any MSKI in general.

Conclusion: While footwear choice did not influence MSKI risk in USCG recruits, female sex was a primary, nonmodifiable intrinsic risk factor.

Key Words: Military Health; Shoes; Running; Physical Conditioning, Human; Wounds and Injuries

\section{Key Points:}

- Self-selection of athletic footwear was not a significant factor for MSKI in USCG recruits, despite widespread reports of discomfort and perceived deleterious effects of wear.

- MSKI continues to be a major source of morbidity in the recruit training population, with female sex found to be a robust and significant factor regardless of footwear choice.

- While there is no indication that prescribed athletic footwear is associated with MSKI, policymakers should factor in individual preference when considering the mandate for wear. 
medRxiv preprint doi: https://doi.org/10.1101/2022.01.03.22268706; this version posted January 5, 2022. The copyright holder for this preprint

(which was not certified by peer review) is the author/funder, who has granted medRxiv a license to display the preprint in perpetuity.

This article is a US Government work. It is not subject to copyright under 17 USC 105 and is also made available for use under a CCO license.

\section{INTRODUCTION}

Musculoskeletal injuries (MSKIs) are ubiquitous during initial entry military training, impacting $12-22 \%$ of all recruits, ${ }^{1-3}$ with overuse injuries in the lower extremities the most frequent. ${ }^{4-6} \mathrm{~A}$ common mechanism for overuse injuries is running, ${ }^{7}$ an activity that is an integral part of United States Coast Guard (USCG) training and a requirement for graduation. Therefore, it is important to understand the factors, including the impact of footwear, that may contribute to MSKI risk. Athletic footwear forms the interface between the foot and ground during running and is hypothesized to affect running-related injuries (RRIs) through control of ankle-foot kinetics and kinematics. ${ }^{8}$ More recently, the focus of injury risk has been on modifiable movement patterns such as foot strike type, cadence and running surface, all of which can affect factors related to injury risk, such as average and peak loading rate, peak hip adduction, and knee flexion angle at landing. ${ }^{9-12}$ While footwear type (i.e., minimalist, motion control, etc.) often affects running mechanics, ${ }^{10,13}$ a direct association between running footwear and injury risk has yet to be established..$^{8,14,15}$ It has been suggested that self-selection of comfortable shoes with a preferred movement path is more closely associated with injury prevention. ${ }^{8,16}$

In 1941, the US Congress passed the Berry Amendment to promote domestic commerce through the obligated purchase of American-made products by the military, which includes uniforms. Historically, athletic footwear was not considered a uniform item. However, the 2017 National Defense Authorization Act included an interpretation that Berry Amendment-compliant athletic footwear be included with the enlisted recruit uniform issue to "provide sufficient choices to minimize the incidence of athletic injuries in initial entry training." ${ }^{17}$ In response to this determination, the USCG Training Center (TRACEN) began mandating the use of prescribed athletic footwear in the first quarter of 2018 and required all recruits to wear them 
medRxiv preprint doi: https://doi.org/10.1101/2022.01.03.22268706; this version posted January 5, 2022. The copyright holder for this preprint (which was not certified by peer review) is the author/funder, who has granted medRxiv a license to display the preprint in perpetuity.

This article is a US Government work. It is not subject to copyright under 17 USC 105 and is also made available for use under a CCO license.

during training, regardless of their preferred footwear or prior running experience. Additionally, scheduling density during the recruit training pipeline typically precluded the necessary time to adequately assess fit and comfort during uniform issue or acclimatize recruits to the footwear prior to training, which could plausibly contribute to increased MSKI risk. ${ }^{8,18,19}$

Acknowledging that self-selection of athletic footwear may influence MSKI in the recruit population while still ensuring adequate footwear was provided to recruits regardless of their pre-enlistment socioeconomic status, a proof-of-concept project was initiated in October 2019 that allowed recruits a choice to either wear the prescribed Berry-compliant athletic footwear or their own footwear. Due to the potential for this policy change to influence injury outcomes, empirical assessment of the effects of this policy is warranted. Therefore, the purpose of this retrospective cohort study was to assess the effects of athletic footwear choice on lower quarter MSKI risk, while factoring the influences of age, sex, height, body mass, and physical fitness level as assessed by run time from the Physical Fitness Assessment (PFA). A secondary aim was to assess the perceived form, fit, and function of prescribed uniform footwear in all recruits.

\section{METHODS}

This was a retrospective cohort study that included a sample of recruits stationed at the USCG TRACEN, Cape May, New Jersey, from March 2018 to March 2020. Ethics approval was provided by the USCG Institutional Review Board as exempt research. The Strengthening the Reporting of Observational studies in Epidemiology (STROBE) ${ }^{20}$ was used to guide reporting of this study.

\section{Data Sources}


medRxiv preprint doi: https://doi.org/10.1101/2022.01.03.22268706; this version posted January 5, 2022. The copyright holder for this preprint (which was not certified by peer review) is the author/funder, who has granted medRxiv a license to display the preprint in perpetuity.

This article is a US Government work. It is not subject to copyright under 17 USC 105 and is also made available for use under a CCO license.

Recruit age, sex, height, body mass, and run time on the PFA were derived from administrative records maintained by USCG TRACEN. Injury data, including the diagnosis, body segment, and the attributed mechanism of injury, were abstracted from a medical tracking database maintained by USCG TRACEN medical personnel. Additionally, data from a process improvement project, which solicited feedback from all recruits on the form, fit, and function of the issued athletic footwear, were also examined.

\section{Cohort Selection}

A sample of 2876 recruits (2260 males, 616 females) stationed at USCG TRACEN from 01 October 2018 to 30 September 2019, who trained under the policy that required obligatory wear of Berry-compliant athletic shoes, were included in the control group. Figure 1 details the prescribed uniform running footwear manufactured by New Balance Athletics, Inc. (Boston, MA, USA) and San Antonio Shoemakers (SAS; San Antonio, TX, USA) for the US Department of Defense that were available at USCG TRACEN during the study epoch. A sample of 1229 recruits (1038 males, 191 females) stationed at USCG TRACEN from 01 October 2019 to 31 March 2020, a time where a shift in administrative policy allowed for the use of self-selected athletic footwear during training, comprised the experimental group. The exposure was consistent for both cohorts as the training curriculum, mode, and frequency of physical training at USCG TRACEN were similar during the study epoch. Since several intrinsic risk factors may contribute to lower quarter injury, ${ }^{21}$ age, sex, height, body mass, and PFA run scores were collected.

\section{Outcome Variables}


medRxiv preprint doi: https://doi.org/10.1101/2022.01.03.22268706; this version posted January 5, 2022. The copyright holder for this preprint

(which was not certified by peer review) is the author/funder, who has granted medRxiv a license to display the preprint in perpetuity.

This article is a US Government work. It is not subject to copyright under 17 USC 105 and is also made available for use under a CCO license.

Recruits who presented to the medical treatment facility at TRACEN for any lower quarter MSKI during training were counted as having an outcome. Since footwear choice may influence certain types of injuries over others, characteristics of the injury type (e.g., bone stress injury and medial tibial stress syndrome [MTSS]), body region (e.g., hip, knee, ankle-foot), and attributed mechanism (e.g., running) were derived from the medical database. For this study, the specific diagnostic categories of interest included ankle-foot complex injuries (specifically involving the tibia, fibula, ankle, or foot), MTSS or bone stress injuries (involving any bone in the lower quarter), RRI (any lower quarter injury specifically attributed to running), overuse injuries (any lower quarter injuries that were not caused by a macrotraumatic event), and all MSKIs (which encompassed both repetitive microtraumatic and macrotraumatic injuries). Given that these categories are not mutually exclusive, a recruit with an injury could potentially be counted in one or multiple categories. For example, a recruit that presented for a tibial bone stress injury from running would be categorized in each of the five categorizations of injury outcomes employed in this study. In contrast, a recruit with anterior knee pain experienced during squatting would only be classified in the overuse injuries and all MSKI categories. If no clear mechanism was identified by the recruit, idiopathic MSKI was assumed to be a result of a repetitive overuse injury. ${ }^{22}$

\section{Perceived Form, Fit, and Function of Berry-Compliant Prescribed Athletic Footwear}

A process improvement project was conducted from April 2019 to September 2019 that solicited feedback pertaining to the form, fit, and function of the prescribed uniform athletic footwear among all USCG recruits $(\mathrm{n}=922)$ upon graduation. These recruits were asked to rate the level of satisfaction with the issued athletic footwear (5-point Likert scale: 1=very dissatisfied, $3=$ neutral, $5=$ very satisfied); if they ever suffered any pain with these shoes, 
medRxiv preprint doi: https://doi.org/10.1101/2022.01.03.22268706; this version posted January 5, 2022. The copyright holder for this preprint (which was not certified by peer review) is the author/funder, who has granted medRxiv a license to display the preprint in perpetuity.

This article is a US Government work. It is not subject to copyright under 17 USC 105 and is also made available for use under a CCO license.

(yes/no); have they ever suffered an injury as a result of wearing these shoes (yes/no); how much of an effect did the shoes have on their running performance (5-point Likert scale: $1=$ ran significantly slower, $3=$ no effect, $5=$ ran significantly faster); and which of the following footwear would you prefer (issued uniform athletic footwear or self-selected habitual athletic footwear).

\section{Statistical Approach}

The level of significance was $p<0.05$ for all analyses. Descriptive statistics were calculated for both the experimental and control groups. To evaluate the effects of the prescribed athletic footwear on MSKI risk, a multivariable logistic regression was performed modeling the effects of experimental group (referenced to prescribed footwear controls), age, female sex (referenced to male recruits), height, body mass, PFA run scores, and the interactions of experimental group by body mass and experimental group by female sex. Analyses were performed using the survival package (version 3.2-10) in R version 3.5.1 (The R Foundation for Statistical Computing, Vienna, Austria). Odds ratios (ORs) and 95\% confidence intervals (CIs) were calculated for each significant predictor using the exponentiated log odds. For the secondary aim of assessing the results of feedback pertaining to the form, fit, and function of the prescribed footwear, descriptive statistics of responses were reported.

\section{RESULTS}

Figure 2 details the group demographics. The control group had greater mean age $(\leq 1$ year) and a lower proportion of females that comprised the group (control group: 15.7\%; experimental group: $21.4 \%$ ). There were no other statistically significant differences in group 
medRxiv preprint doi: https://doi.org/10.1101/2022.01.03.22268706; this version posted January 5, 2022. The copyright holder for this preprint (which was not certified by peer review) is the author/funder, who has granted medRxiv a license to display the preprint in perpetuity. This article is a US Government work. It is not subject to copyright under 17 USC 105 and is also made available for use under a CCO license.

demographics. When stratified by sex, there were significant differences in recruit characteristics, with female recruits exhibiting greater mean age ( $\leq 1$ year), shorter height, lower body mass, and longer run times.

Figure 3 details the prevalence of MSKI in the experimental and control groups. There were no significant differences in MSKI between groups for any of the injuries or injury mechanisms reported (Table 1). Ankle-foot, leg, knee, and lumbopelvic-hip complex complaints were ubiquitous in both groups, ranging from 20.37 to 29.34 per 1000 recruits in the experimental group and 18.08 to 25.59 per 1000 recruits in the control group. Thigh injuries were comparatively scarcer, with a prevalence of 4.89 per 1000 recruits in the experimental group and 2.73 per 1000 recruits in the control group. When characterizing the type of injuries, overuse injuries were predominant (experimental group: 96.17 per 1000 recruits; control group: 86.32 per 1000 recruits) compared with traumatic injuries (experimental group: 11.41 per 1000 recruits; control group: 5.46 per 1000 recruits). Among overuse injuries, RRIs were a substantial burden in both the experimental (72.53 per 1000 recruits) and control (64.14 per 1000 recruits) groups. MTSS and bone stress injuries occurred in about one third of RRIs. When considering all injuries, the burden was 107.58 per 1000 recruits in the experimental group and 91.78 per 1000 recruits in the control group.

The results of the multivariable logistic regression analysis are reported in Table 1. Group was not a significant factor for any of the injuries assessed. Sex was a significant factor in all injury types, with female recruits demonstrating $\sim 2.00$ greater odds of experiencing an RRI, overuse injuries, or any MSKI in general. When considering ankle-foot, MTSS, or bone stress injuries, the risk in female recruits increased to 3.73 to 4.11 greater odds than their male counterparts. Run time was a significant predictor in RRI, all overuse injuries, and for any injury 
medRxiv preprint doi: https://doi.org/10.1101/2022.01.03.22268706; this version posted January 5, 2022. The copyright holder for this preprint (which was not certified by peer review) is the author/funder, who has granted medRxiv a license to display the preprint in perpetuity.

This article is a US Government work. It is not subject to copyright under 17 USC 105 and is also made available for use under a CCO license.

(OR range 1.15-1.21. A significant but small magnitude increased risk was observed for the factors of greater age and a small magnitude protective effect was observed for greater body mass. The interactions of experimental group by body mass and experimental group by female sex were not significant (OR and CI crossed a 1.00 threshold, $p>0.05$ ) for any injury type and were removed from the final models.

Table 2 details the results of the survey pertaining to the form, fit, and function of prescribed footwear in all recruits. The majority (58.6\%) of the respondents reported pain and $15.7 \%$ attributed an MSKI to wearing the prescribed uniform footwear. Pertaining to perceived effect on running performance, approximately one quarter of the respondents reported a deleterious effect, $10.4 \%$ reported an advantageous effect, and $63.3 \%$ reported no effect. Approximately one quarter of the respondents reported satisfaction with the prescribed footwear, approximately one half reported being dissatisfied, with the remaining one quarter reporting neutrality. The prescribed uniform footwear was the preferred footwear of $29.3 \%$ of the respondents, with only $12.3 \%$ reporting continued use of the footwear following graduation.

\section{DISCUSSION}

This study retrospectively investigated whether MSKI risk differed between USCG recruits who were uniformly prescribed Berry-compliant athletic footwear versus those who were free to choose their own athletic footwear. We found that choice of athletic footwear had no significant effect on MSKI in USCG recruits. This is despite the widespread report of discomfort and dissatisfaction of the prescribed athletic footwear observed in the feedback provided by the recruits. Our study also confirms that MSKI continues to be a major source of morbidity in the 
medRxiv preprint doi: https://doi.org/10.1101/2022.01.03.22268706; this version posted January 5, 2022. The copyright holder for this preprint (which was not certified by peer review) is the author/funder, who has granted medRxiv a license to display the preprint in perpetuity. This article is a US Government work. It is not subject to copyright under 17 USC 105 and is also made available for use under a CCO license.

recruit training population, with female sex found to be a robust and significant factor regardless of footwear choice.

Use of the prescribed athletic footwear did not increase the risk of MSKI, despite reported perceived attribution. These findings are consistent with high-level evidence that the use of prescribed footwear in the recruit and active duty military populations is neither protective nor contributory to MSKI. ${ }^{18,23}$ This also supports the findings of Bullock and colleagues ${ }^{24}$ who concluded that that there was insufficient evidence to recommend prescribed footwear given that arch height and replacement of footwear at regular intervals did not significantly influence MSKI. Saragiotto and colleagues ${ }^{25}$ studied perceptions of the role of foot morphology and athletic footwear in recreational runners and found that about one third of the participants attributed foot morphology to RRI and viewed footwear as especially salient for prevention. ${ }^{25}$ Some of these same beliefs were expressed by Wolthon and colleagues ${ }^{26}$ who reported continued belief in the contribution of footwear toward MSKI among both physical therapists and nonclinicians. Despite the dissatisfaction with the prescribed athletic footwear in our current study and individuals' perceived association of footwear and MSKI reported by others studies, ${ }^{25,26}$ our results support the conclusions of many others ${ }^{8,14,15,18,23,24}$ that athletic footwear appears to have no significant influence on MSKI. It is highly plausible that the perceptions reported by the USCG recruits may be shaped through social mechanisms, especially if other recruits were vocal about their dislike of the footwear. This may explain the disparity between the widespread subjective discomfort and lack of objective association of the prescribed footwear with MSKI observed in our study. This supposition, and some of the qualitative factors that contribute to dissatisfaction, warrant further investigation. 
medRxiv preprint doi: https://doi.org/10.1101/2022.01.03.22268706; this version posted January 5, 2022. The copyright holder for this preprint (which was not certified by peer review) is the author/funder, who has granted medRxiv a license to display the preprint in perpetuity. This article is a US Government work. It is not subject to copyright under 17 USC 105 and is also made available for use under a CCO license.

Our findings align with a previous report on a similar training population that identified female sex as a significant factor for MSKI. Cosio and collegaues ${ }^{27}$ conducted a study of USCG cadets during Summer Warfare Annual Basic Training and found increased odds in female recruits for ankle (OR: 2.58), foot (OR: 2.07), bone stress (OR: 1.13), and overuse (OR: 1.72) injuries. Slower run times were also found to be associated with MSKI in the same study. ${ }^{27}$ Our findings also diverge from a recent systematic review with meta-analysis that found while sex was a factor for MSKI in female military members, it was not a significant factor for repetitive overuse injuries. ${ }^{21}$ We observed large and significant effects for female sex in each injury type in the multivariable assessment, including specifically MTSS and bone stress injury (OR: 4.11, 95\% CI: 1.34-12.62), RRI (OR: 2.30, 95\% CI: 1.21-4.38), and overuse injuries (OR: 2.02, 95\% CI: 1.13-3.64). These findings also agree with an increased risk of ankle-foot complex fractures observed among Navy enlisted females compared with their male counterparts. ${ }^{28}$

\section{Clinical and Policy Recommendations}

While there is no indication that the Berry-compliant prescribed athletic footwear is associated with MSKI, policymakers should factor in individual preference when considering the mandate for wear. Based on the reported dissatisfaction, perceived discomfort, and the low proportion of Coast Guardsmen who intended to continue use of the prescribed footwear beyond the 8-week recruit training, return on investment for this appropriation should be considered. To balance the domestic commercial benefits of purchasing Berry-compliant prescribed athletic footwear with the individual needs of the service member, it is recommended that all stakeholders (recruit training leadership, instructor cadre, and recent recruits) be involved during the contracting process by wear-testing and providing feedback to establish best value. This will 
medRxiv preprint doi: https://doi.org/10.1101/2022.01.03.22268706; this version posted January 5, 2022. The copyright holder for this preprint (which was not certified by peer review) is the author/funder, who has granted medRxiv a license to display the preprint in perpetuity.

This article is a US Government work. It is not subject to copyright under 17 USC 105 and is also made available for use under a CCO license.

help ensure continued use of issued athletic footwear beyond recruit training and maximize the return on investment of appropriated funds.

While the schedule at recruit training is constrained and precludes time for the recommended sufficient transition period to the new footwear, ${ }^{29}$ allocating time for proper fitting, distribution, and acclimatization to the footwear upon arrival at TRACEN could remedy this barrier. Lastly, it is also recommended that the instructor cadre and clinicians at TRACEN clearly communicate to recruits that there is no reliable evidence linking athletic footwear with the prevention (or contribution to development) of RRI. ${ }^{29}$ This may help to dispel any preconceived beliefs or attitudes toward the prescribed footwear.

There are limitations to this study. Consistent with USCG records management policies, administrative records are routinely destroyed at the end of the life cycle. As such, a portion of the administrative records containing the demographic information of height, mass, and PFA run times of both groups were not available at the initiation of this study. While this precluded analysis of all recruits during this study epoch and may have introduced bias, these records were destroyed randomly and a large representative sample was nevertheless included.

\section{CONCLUSION}

Self-selection of athletic footwear was not a significant factor for MSKI in USCG recruits, despite widespread reports of discomfort and perceived deleterious effects of wear. MSKI continues to be a major source of morbidity in the recruit training population, with female sex found to be a robust and significant factor to these outcomes regardless of footwear choice. 
medRxiv preprint doi: https://doi.org/10.1101/2022.01.03.22268706; this version posted January 5, 2022. The copyright holder for this preprint

(which was not certified by peer review) is the author/funder, who has granted medRxiv a license to display the preprint in perpetuity.

This article is a US Government work. It is not subject to copyright under 17 USC 105 and is also made available for use under a CCO license.

\section{REFERENCES}

1. Bonanno DR, Munteanu SE, Murley GS, Landorf KB, Menz HB. Risk factors for lower limb injuries during initial naval training: a prospective study. $J$ R Army Med Corps. 2018;164(5):347-351. doi:10.1136/jramc-2018-000919

2. Kaufman KR, Brodine S, Shaffer R. Military training-related injuries: surveillance, research, and prevention. Am J Prev Med. 2000;18(3 Suppl):54-63.

3. Jensen AE, Laird M, Jameson JT, Kelly KR. Prevalence of Musculoskeletal Injuries Sustained During Marine Corps Recruit Training. Mil Med. 2019;184(Supplement_1):511520. doi:10.1093/milmed/usy387

4. Hauret KG, Jones BH, Bullock SH, Canham-Chervak M, Canada S. Musculoskeletal Injuries: Description of an Under-Recognized Injury Problem Among Military Personnel. Am J Prev Med. 2010;38(1, Supplement):S61-S70. doi:10.1016/j.amepre.2009.10.021

5. Taanila H, Suni JH, Kannus P, et al. Risk factors of acute and overuse musculoskeletal injuries among young conscripts: a population-based cohort study. BMC Musculoskelet Disord. 2015;16. doi:10.1186/s12891-015-0557-7

6. Knapik JJ, Graham BS, Rieger J, Steelman R, Pendergrass T. Activities Associated With Injuries in Initial Entry Training. Mil Med. 2013;178(5):500-506. doi:10.7205/MILMED-D$12-00507$

7. Hollander K, Rahlf AL, Wilke J, et al. Sex-Specific Differences in Running Injuries: A Systematic Review with Meta-Analysis and Meta-Regression. Sports Med. 2021;51(5):1011-1039. doi:10.1007/s40279-020-01412-7 
medRxiv preprint doi: https://doi.org/10.1101/2022.01.03.22268706; this version posted January 5, 2022. The copyright holder for this preprint

(which was not certified by peer review) is the author/funder, who has granted medRxiv a license to display the preprint in perpetuity.

This article is a US Government work. It is not subject to copyright under 17 USC 105 and is also made available for use under a CCO license.

8. Nigg BM, Baltich J, Hoerzer S, Enders H. Running shoes and running injuries: mythbusting and a proposal for two new paradigms: 'preferred movement path' and 'comfort filter.' $B r J$ Sports Med. 2015;49(20):1290-1294. doi:10.1136/bjsports-2015-095054

9. Milner CE, Davis IS, Hamill J. Free moment as a predictor of tibial stress fracture in distance runners. J Biomech. 2006;39(15):2819-2825.

10. Baltich J, Maurer C, Nigg BM. Increased vertical impact forces and altered running mechanics with softer midsole shoes. PloS One. 2015;10(4):e0125196.

11. Pohl MB, Mullineaux DR, Milner CE, Hamill J, Davis IS. Biomechanical predictors of retrospective tibial stress fractures in runners. J Biomech. 2008;41(6):1160-1165.

12. Ferber R, Noehren B, Hamill J, Davis I. Competitive female runners with a history of iliotibial band syndrome demonstrate atypical hip and knee kinematics. J Orthop Sports Phys Ther. 2010;40(2):52-58.

13. Hoitz F, Mohr M, Asmussen M, Lam WK, Nigg S, Nigg B. The effects of systematically altered footwear features on biomechanics, injury, performance, and preference in runners of different skill level: a systematic review. Footwear Sci. 2020;12(3):193-215.

14. Dubois B, Esculier JF, Frémont P, Moore L, Richards C. Effects of minimalist and traditional running shoes on injury rates: a pilot randomised controlled trial. Footwear Sci. 2015;7(3):159-164. 
medRxiv preprint doi: https://doi.org/10.1101/2022.01.03.22268706; this version posted January 5, 2022. The copyright holder for this preprint

(which was not certified by peer review) is the author/funder, who has granted medRxiv a license to display the preprint in perpetuity.

This article is a US Government work. It is not subject to copyright under 17 USC 105 and is also made available for use under a CCO license.

15. Daoud AI, Geissler GJ, Wang F, Saretsky J, Daoud YA, Lieberman DE. Foot strike and injury rates in endurance runners: a retrospective study. Med Sci Sports Exerc. 2012;44(7):1325-1334.

16. Mohr M, Meyer C, Nigg S, Nigg B. The relationship between footwear comfort and variability of running kinematics. Footwear Sci. 2017;9(sup1):S45-S47. doi:10.1080/19424280.2017.1314329

17. US Congress. S. 2943 National Defense Authorization Act for Fiscal Year 2017. Published online 2017. Accessed October 5, 2021. https://www.congress.gov/bill/114thcongress/senate-bill/2943

18. Knapik JJ, Trone DW, Tchandja J, Jones BH. Injury-Reduction Effectiveness of Prescribing Running Shoes on the Basis of Foot Arch Height: Summary of Military Investigations. $J$ Orthop Sports Phys Ther. 2014;44(10):805-812. doi:10.2519/jospt.2014.5342

19. Molloy JM. Factors Influencing Running-Related Musculoskeletal Injury Risk Among U.S. Military Recruits. Mil Med. 2016;181(6):512-523. doi:10.7205/MILMED-D-15-00143

20. von Elm E, Altman DG, Egger M, Pocock SJ, Gøtzsche PC, Vandenbroucke JP. The Strengthening the Reporting of Observational Studies in Epidemiology (STROBE) Statement: Guidelines for reporting observational studies. Int J Surg. 2014;12(12):14951499. doi:10.1016/j.ijsu.2014.07.013

21. Rhon DI, Molloy JM, Monnier A, Hando BR, Newman PM. Much work remains to reach consensus on musculoskeletal injury risk in military service members: A systematic review 
medRxiv preprint doi: https://doi.org/10.1101/2022.01.03.22268706; this version posted January 5, 2022. The copyright holder for this preprint

(which was not certified by peer review) is the author/funder, who has granted medRxiv a license to display the preprint in perpetuity.

This article is a US Government work. It is not subject to copyright under 17 USC 105 and is also made available for use under a CCO license.

with meta-analysis. Eur J Sport Sci. Published online June 18, 2021:1-19.

doi:10.1080/17461391.2021.1931464

22. Bahr R. No injuries, but plenty of pain? On the methodology for recording overuse symptoms in sports. Br J Sports Med. 2009;43(13):966-972. doi:10.1136/bjsm.2009.066936

23. Paradise SL, Beer JR, Cruz CA, Fechner KM, MacGregor AJ, Fraser JJ. Prescribed footwear and orthoses are not prophylactic in preventing lower extremity injuries in military tactical athletes: a systematic review with meta-analysis. BMJ Mil Health. Published online November 16, 2021:e001955. doi:10.1136/bmjmilitary-2021-001955

24. Bullock SH, Jones BH, Gilchrist J, Marshall SW. Prevention of Physical Training-Related Injuries: Recommendations for the Military and Other Active Populations Based on Expedited Systematic Reviews. Am J Prev Med. 2010;38(1, Supplement):S156-S181. doi:10.1016/j.amepre.2009.10.023

25. Saragiotto BT, Yamato TP, Lopes AD. What Do Recreational Runners Think About Risk Factors for Running Injuries? A Descriptive Study of Their Beliefs and Opinions. J Orthop Sports Phys Ther. 2014;44(10):733-738. doi:10.2519/jospt.2014.5710

26. Wolthon A, Nielsen RO, Willy RW, Taylor-Haas JA, Paquette MR. Running shoes, pronation, and injuries: do beliefs of injury risk factors among running shoe salespersons and physiotherapy students align with current aetiology frameworks? Footwear Sci. 2020;12(2):101-111. doi:10.1080/19424280.2020.1734869 
medRxiv preprint doi: https://doi.org/10.1101/2022.01.03.22268706; this version posted January 5, 2022. The copyright holder for this preprint

(which was not certified by peer review) is the author/funder, who has granted medRxiv a license to display the preprint in perpetuity.

This article is a US Government work. It is not subject to copyright under 17 USC 105 and is also made available for use under a CCO license.

27. Cosio-Lima LM, Reynolds KL, Knapik JJ, Shumway RS, Irwin W. U.S. Coast Guard Academy injury and risk factor study. $J$ Adv Med Med Res. Published online March 11, 2013:914-927. doi:10.9734/BJMMR/2013/2877

28. MacGregor AJ, Fogleman SA, Dougherty AL, Ryans CP, Janney CF, Fraser JJ. Sex differences in the incidence and risk of ankle-foot complex stress fractures among U.S. military personnel. J Womens Health. Published online November 25, 2021. doi:10.1089/jwh.2021.0292

29. Napier C, Willy RW. Logical fallacies in the running shoe debate: let the evidence guide prescription. Br J Sports Med. 2018;52(24):1552-1553. doi:10.1136/bjsports-2018-100117 
medRxiv preprint doi: https://doi.org/10.1101/2022.01.03.22268706; this version posted January 5, 2022. The copyright holder for this preprint (which was not certified by peer review) is the author/funder, who has granted medRxiv a license to display the preprint in perpetuity.

This article is a US Government work. It is not subject to copyright under 17 USC 105 and is also made available for use under a CCO license.

\section{List of Figures and Tables}

Figure 1. Prescribed uniform running footwear manufactured by (A) New

Balance Athletics, Inc (Boston, MA) and (B) San Antonio Shoemakers

(SAS; San Antonio, TX)

Figure 2. Descriptive statistics of recruits in the Experimental and Control footwear groups

Figure 3. Prevalence of MSKI in the experimental and control groups. 
Table 1. Results of the multiple variable logistic regression analyses modeling musculoskeletal injuries in US Coast Guard recruits

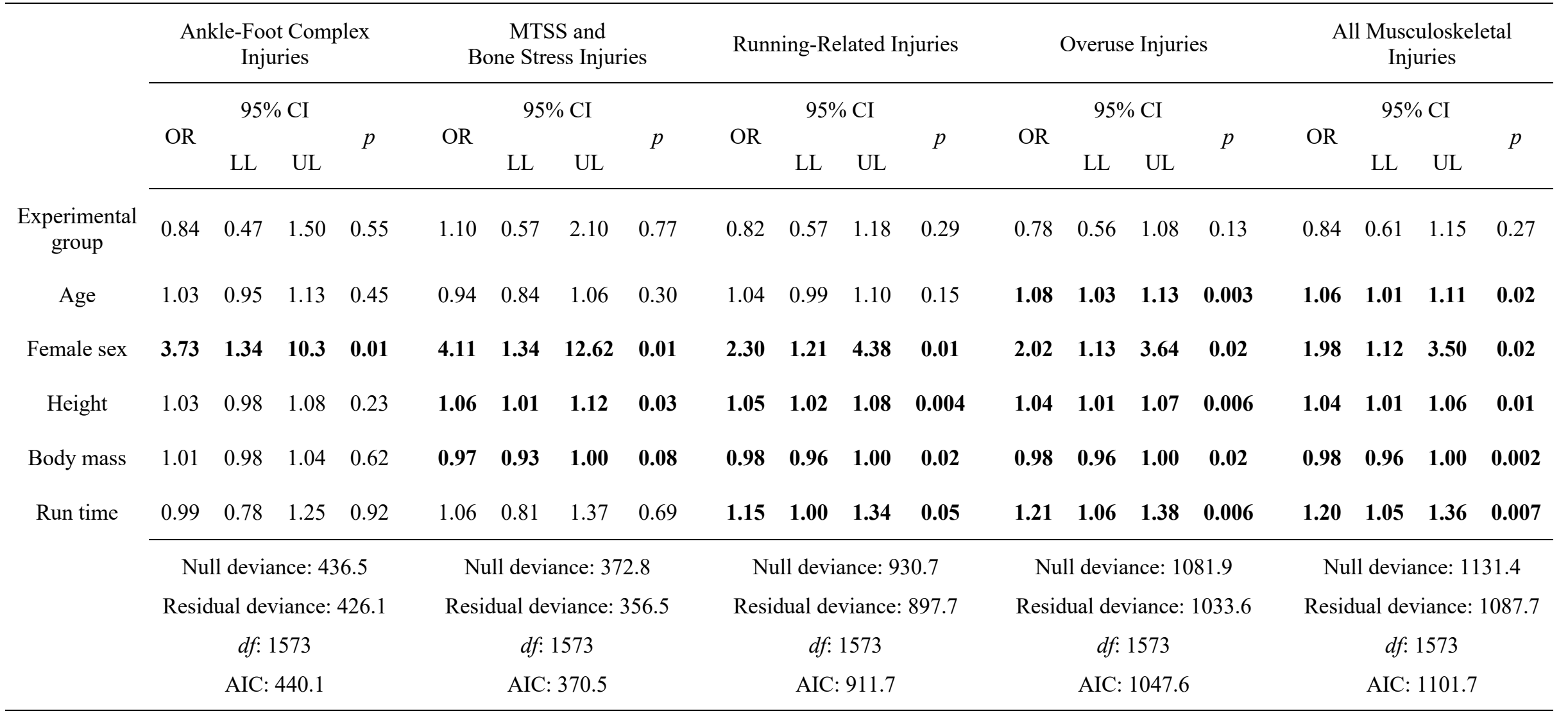

Bolded values indicate statistical significance. MTSS, medial tibial stress syndrome; OR, odds ratio; CI, confidence interval; LL, lower limit; $\mathrm{UL}$, upper limit; $d f$, degrees of freedom; AIC, Akaike information criterion. 
medRxiv preprint doi: https://doi.org/10.1101/2022.01.03.22268706; this version posted January 5, 2022. The copyright holder for this preprint (which was not certified by peer review) is the author/funder, who has granted medRxiv a license to display the preprint in perpetuity.

This article is a US Government work. It is not subject to copyright under 17 USC 105 and is also made available for use under a CCO license.

Table 2. Survey of form, fit, and function of prescribed uniform footwear for all recruits

\begin{tabular}{|c|c|c|c|c|c|c|c|}
\hline & & \multicolumn{2}{|c|}{$\begin{array}{l}\text { New Balance } \\
\qquad(n=869)\end{array}$} & \multicolumn{2}{|c|}{$\begin{array}{l}\text { San Antonio Shoewear } \\
\qquad(\mathrm{n}=53)\end{array}$} & \multicolumn{2}{|c|}{$\begin{array}{c}\text { Total } \\
(\mathrm{n}=922)\end{array}$} \\
\hline & & $\mathrm{n}$ & $\%$ & $\mathrm{n}$ & $\%$ & $\mathrm{n}$ & $\%$ \\
\hline \multicolumn{2}{|c|}{ Reported pain during wear } & 506 & 58.2 & 34 & 64.2 & 540 & 58.6 \\
\hline \multirow{5}{*}{$\begin{array}{c}\text { Injuries attributed } \\
\text { to the prescribed } \\
\text { footwear }\end{array}$} & Ankle-foot complex & 120 & 13.8 & 10 & 18.9 & 130 & 14.1 \\
\hline & Knee & 16 & 1.8 & 1 & 1.9 & 17 & 1.8 \\
\hline & Thigh & 2 & 0.2 & 0 & 0.0 & 2 & 0.2 \\
\hline & Lumbopelvic-hip complex & 10 & 1.2 & 1 & 1.9 & 11 & 1.2 \\
\hline & Total & 135 & 15.5 & 10 & 18.9 & 145 & 15.7 \\
\hline \multirow{5}{*}{$\begin{array}{l}\text { Perceived effect } \\
\text { on running } \\
\text { performance }\end{array}$} & Substantially slower & 42 & 4.8 & 4 & 7.5 & 46 & 5.0 \\
\hline & Slower & 176 & 20.3 & 11 & 20.8 & 187 & 20.3 \\
\hline & No effect & 550 & 63.3 & 34 & 64.2 & 584 & 63.3 \\
\hline & Faster & 85 & 9.8 & 4 & 7.5 & 89 & 9.7 \\
\hline & Substantially faster & 16 & 1.8 & 0 & 0.0 & 16 & 1.7 \\
\hline \multirow{5}{*}{$\begin{array}{l}\text { Satisfaction with } \\
\text { prescribed } \\
\text { uniform footwear }\end{array}$} & Very satisfied & 51 & 5.9 & 6 & 11.3 & 57 & 6.2 \\
\hline & Somewhat satisfied & 197 & 22.7 & 12 & 22.6 & 209 & 22.7 \\
\hline & Neutral & 214 & 24.6 & 10 & 18.9 & 224 & 24.3 \\
\hline & Somewhat dissatisfied & 205 & 23.6 & 11 & 20.8 & 216 & 23.4 \\
\hline & Very dissatisfied & 197 & 22.7 & 14 & 26.4 & 211 & 22.9 \\
\hline \multirow{2}{*}{$\begin{array}{l}\text { Preferred } \\
\text { footwear }\end{array}$} & Prescribed & 256 & 29.5 & 14 & 26.4 & 270 & 29.3 \\
\hline & Control & 613 & 70.5 & 39 & 73.6 & 652 & 70.7 \\
\hline \multicolumn{2}{|c|}{$\begin{array}{l}\text { Intended continued use of prescribed footwear } \\
\text { following graduation }\end{array}$} & 108 & 12.4 & 5 & 9.4 & 113 & 12.3 \\
\hline
\end{tabular}




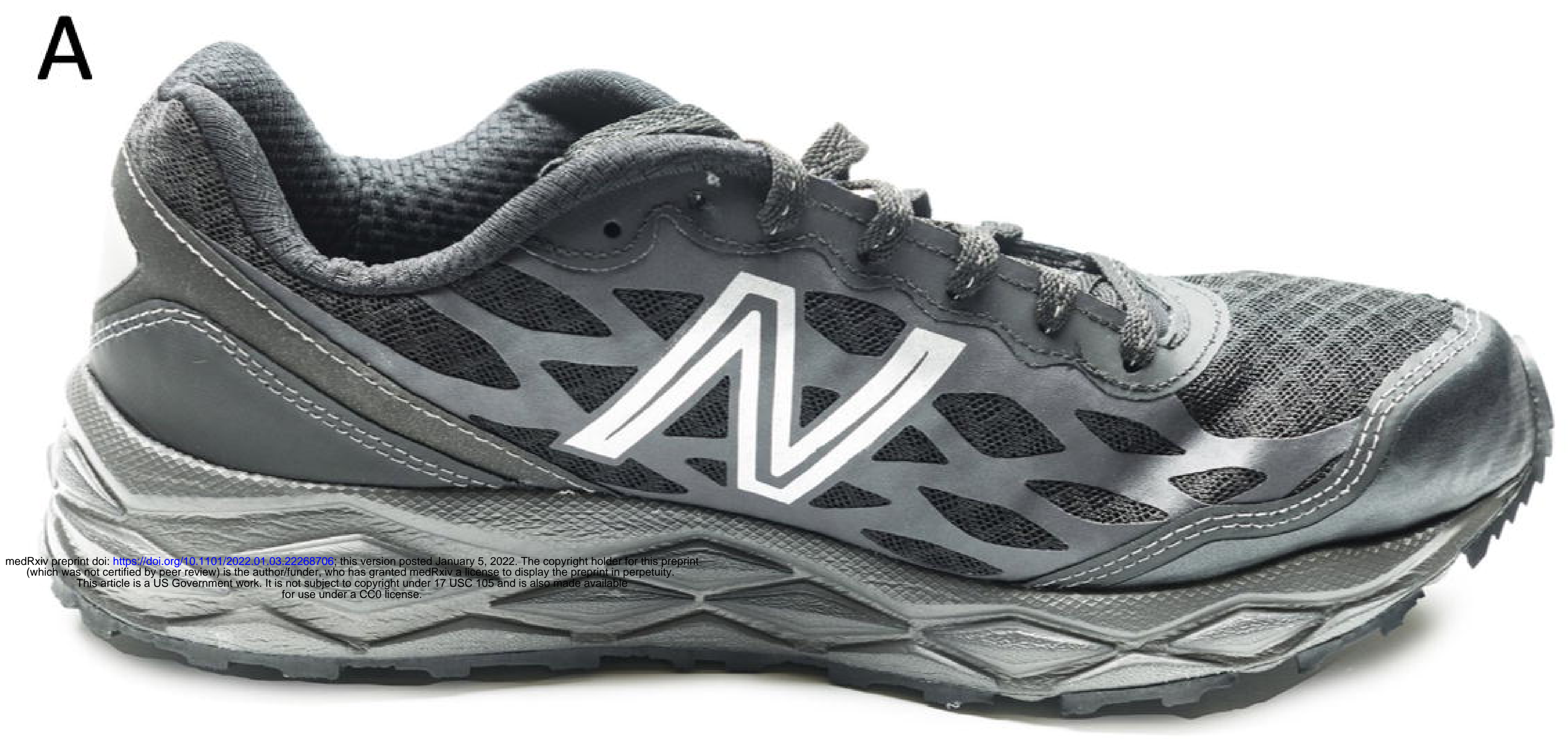

B

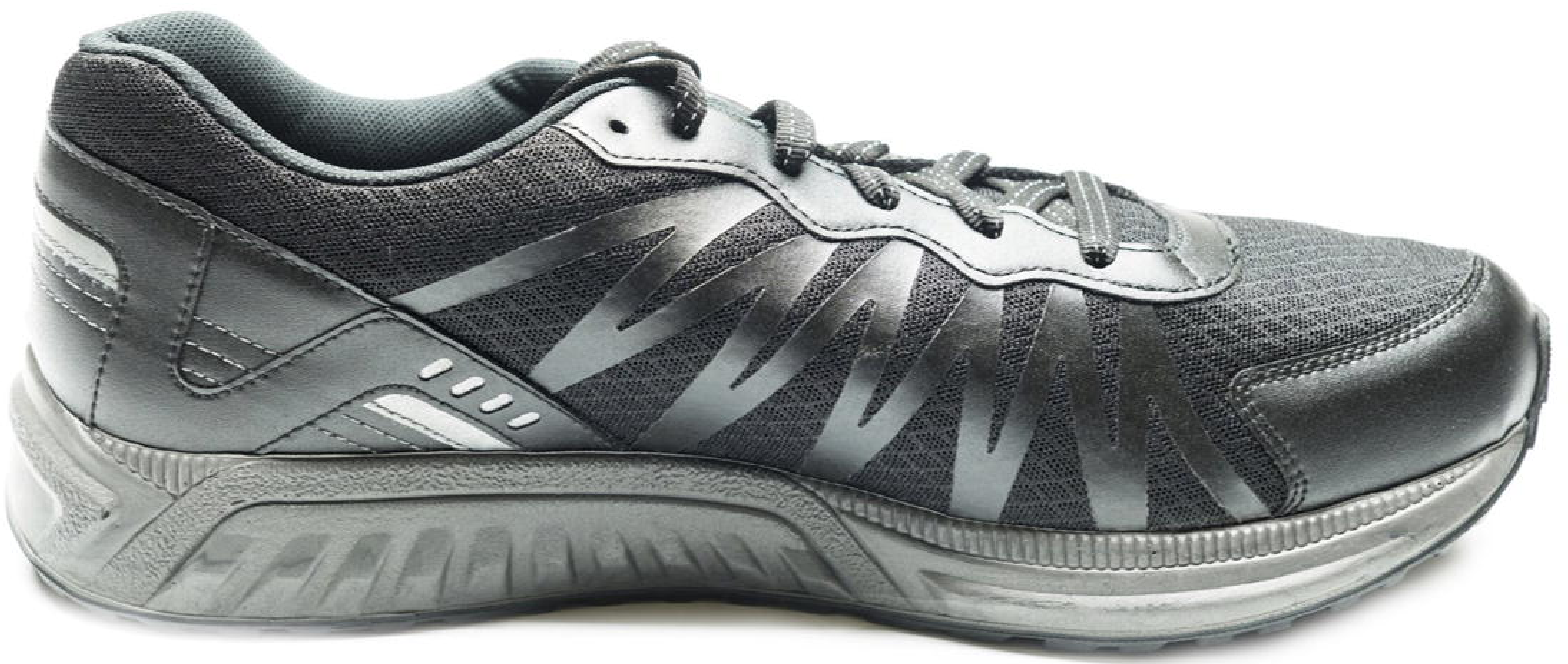


Descriptive statistics of recruits in the Experimental and Control footwear groups

Female Recruits Male Recruits

Experimental,
$\mathrm{n}=144$$\quad \begin{gathered}\text { Experimental, Group } \\ \mathrm{n}=776\end{gathered}$ Sex $\quad \begin{gathered}\text { Group } \\ * \text { Sex }\end{gathered}$

Group

*Sex

Control, $\mathrm{n}=140 \quad$ Control, $\mathrm{n}=514$

\begin{tabular}{|c|c|c|c|c|c|c|}
\hline \multirow[b]{2}{*}{$\begin{array}{c}\text { Age } \\
\text { (years) }\end{array}$} & \multirow[b]{2}{*}{$\begin{array}{c}\text { Experimental } \\
\text { Control }\end{array}$} & \multicolumn{2}{|c|}{ Mean (SD) } & \multirow{2}{*}{$\frac{\mathrm{p}}{<0.001}$} & \multirow{2}{*}{$\frac{\mathrm{p}}{0.003}$} & \multirow{2}{*}{$\frac{\mathrm{p}}{0.07}$} \\
\hline & & $\begin{array}{l}21.8(3.3) \\
20.6(3.7)\end{array}$ & $\begin{array}{l}20.8(3.0) \\
20.4(3.1)\end{array}$ & & & \\
\hline $\begin{array}{c}\text { Height } \\
\text { (cm) }\end{array}$ & $\begin{array}{c}\text { Experimental } \\
\text { Control }\end{array}$ & $\begin{array}{l}162.8(5.7) \\
164.0(6.5)\end{array}$ & $\begin{array}{l}176.6(6.8) \\
176.8(6.6)\end{array}$ & 0.31 & $<0.001$ & 0.20 \\
\hline $\begin{array}{c}\text { Body Mass } \\
\text { (kg) }\end{array}$ & $\begin{array}{c}\text { Experimental } \\
\text { Control }\end{array}$ & $\begin{array}{l}62.8(8.0) \\
65.0(9.9)\end{array}$ & $\begin{array}{c}75.2(10.8) \\
74.9(9.8)\end{array}$ & 0.76 & $<0.001$ & 0.05 \\
\hline $\begin{array}{l}\text { Run Time } \\
\text { (minutes) }\end{array}$ & $\begin{array}{c}\text { Experimental } \\
\text { Control }\end{array}$ & $\begin{array}{l}14.18(1.41) \\
14.17(1.50)\end{array}$ & $\begin{array}{l}11.70(1.10) \\
11.61(1.14)\end{array}$ & 0.24 & $<0.001$ & 0.67 \\
\hline
\end{tabular}
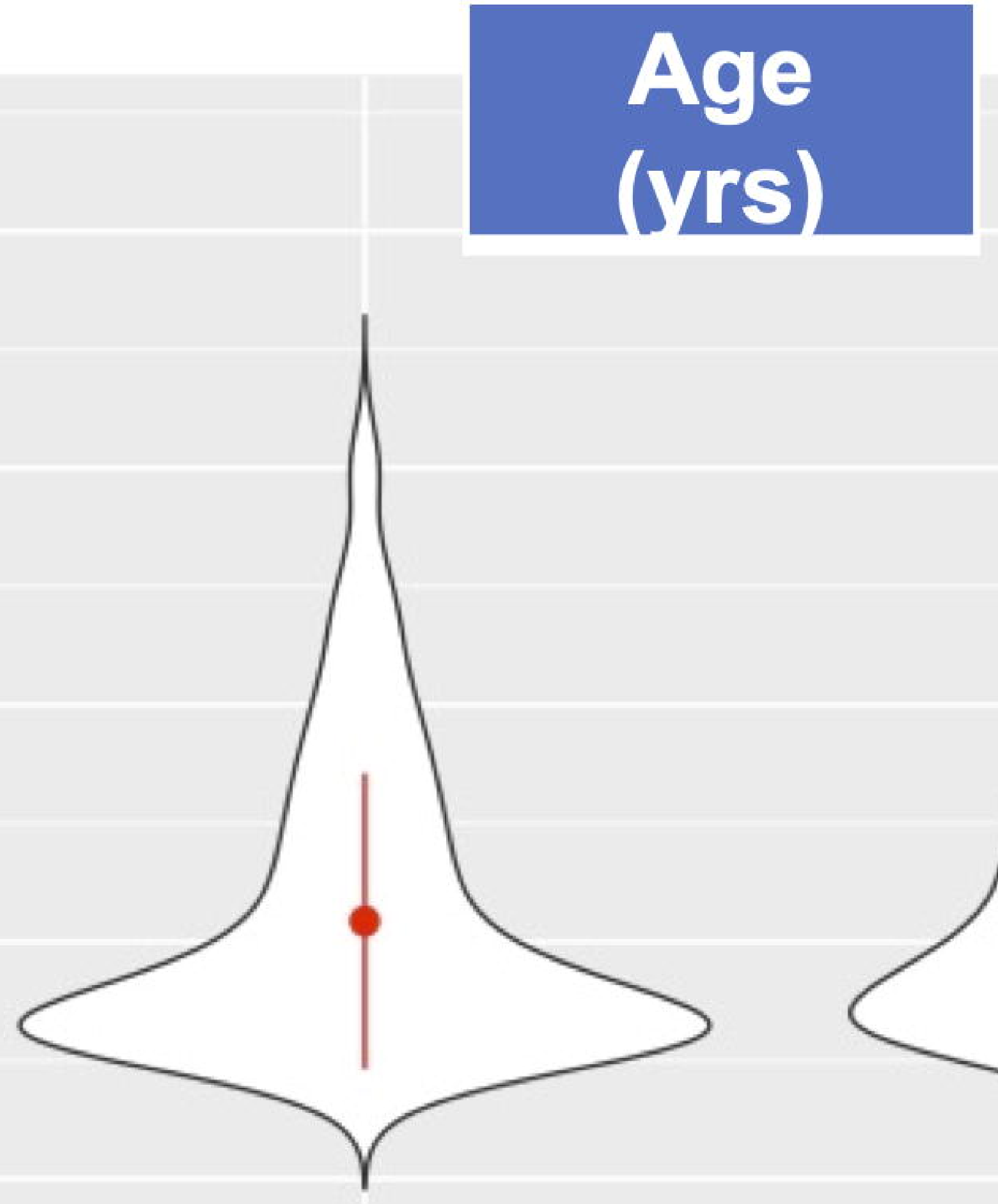

Control

Body Mass

(kg)

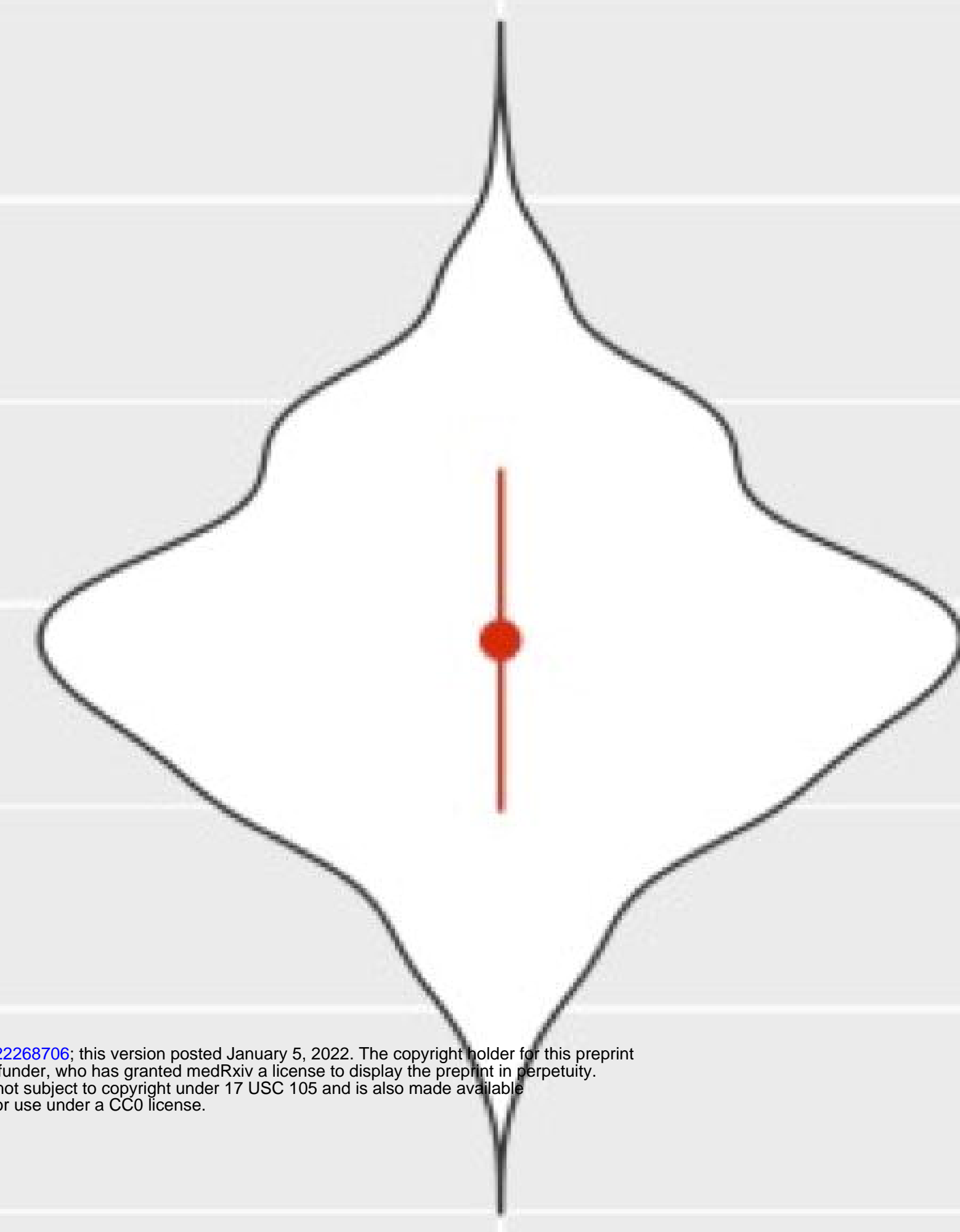

Control

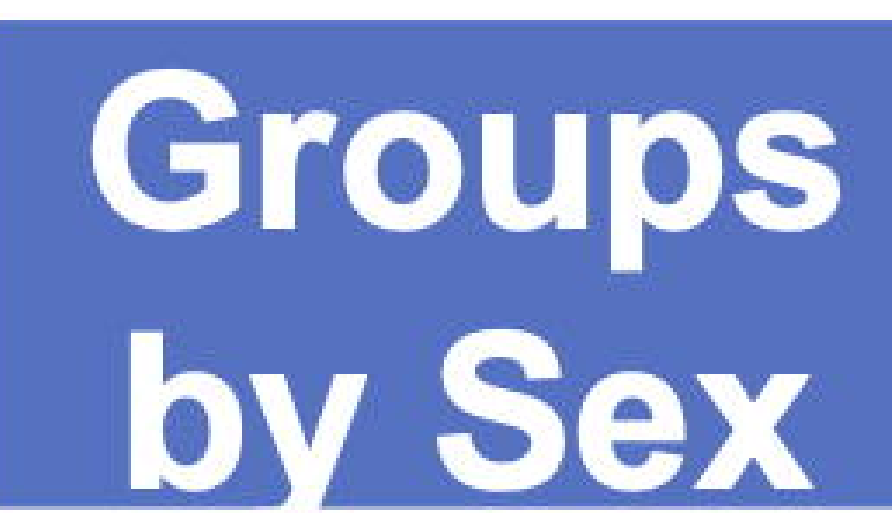

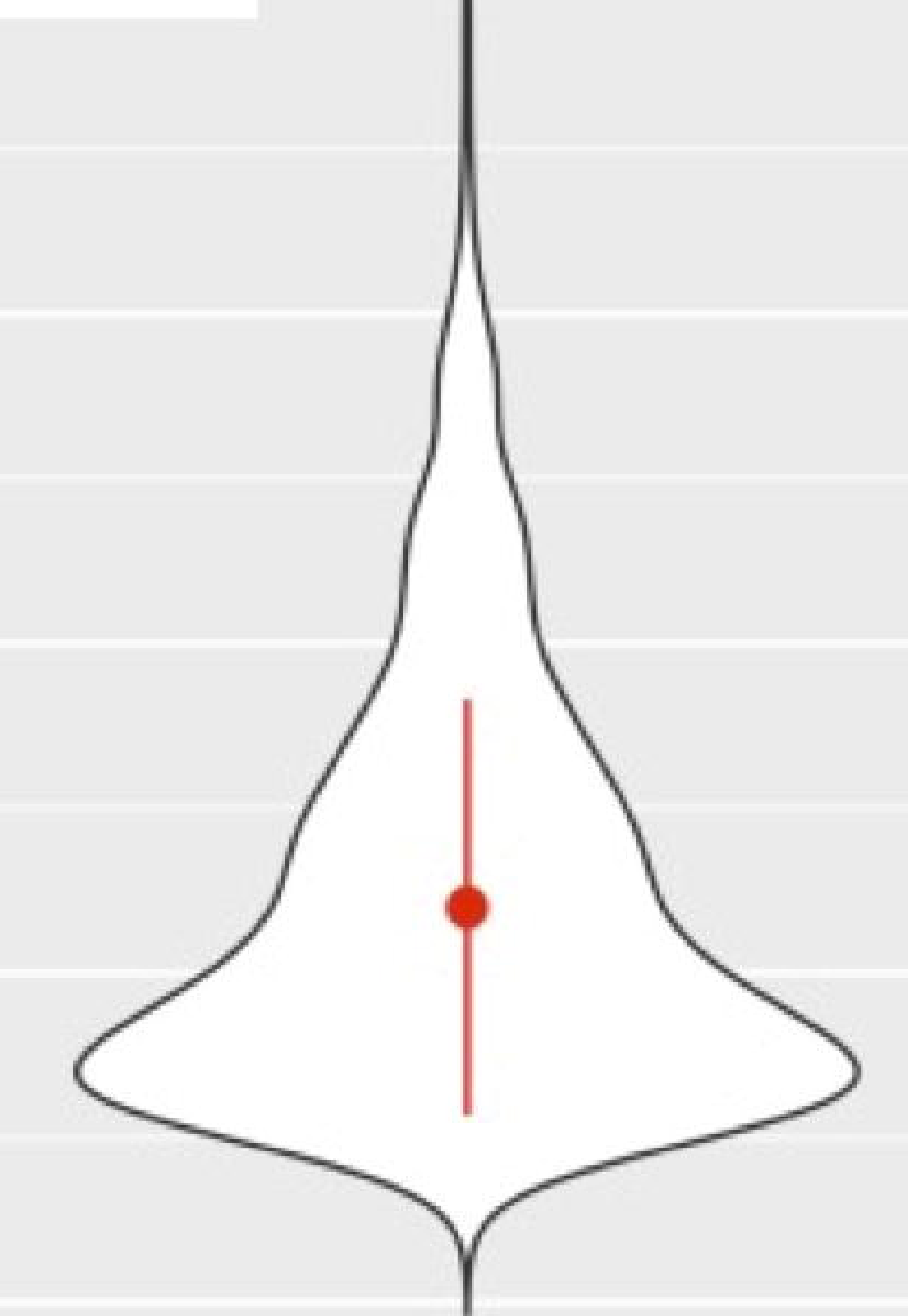

Experimental

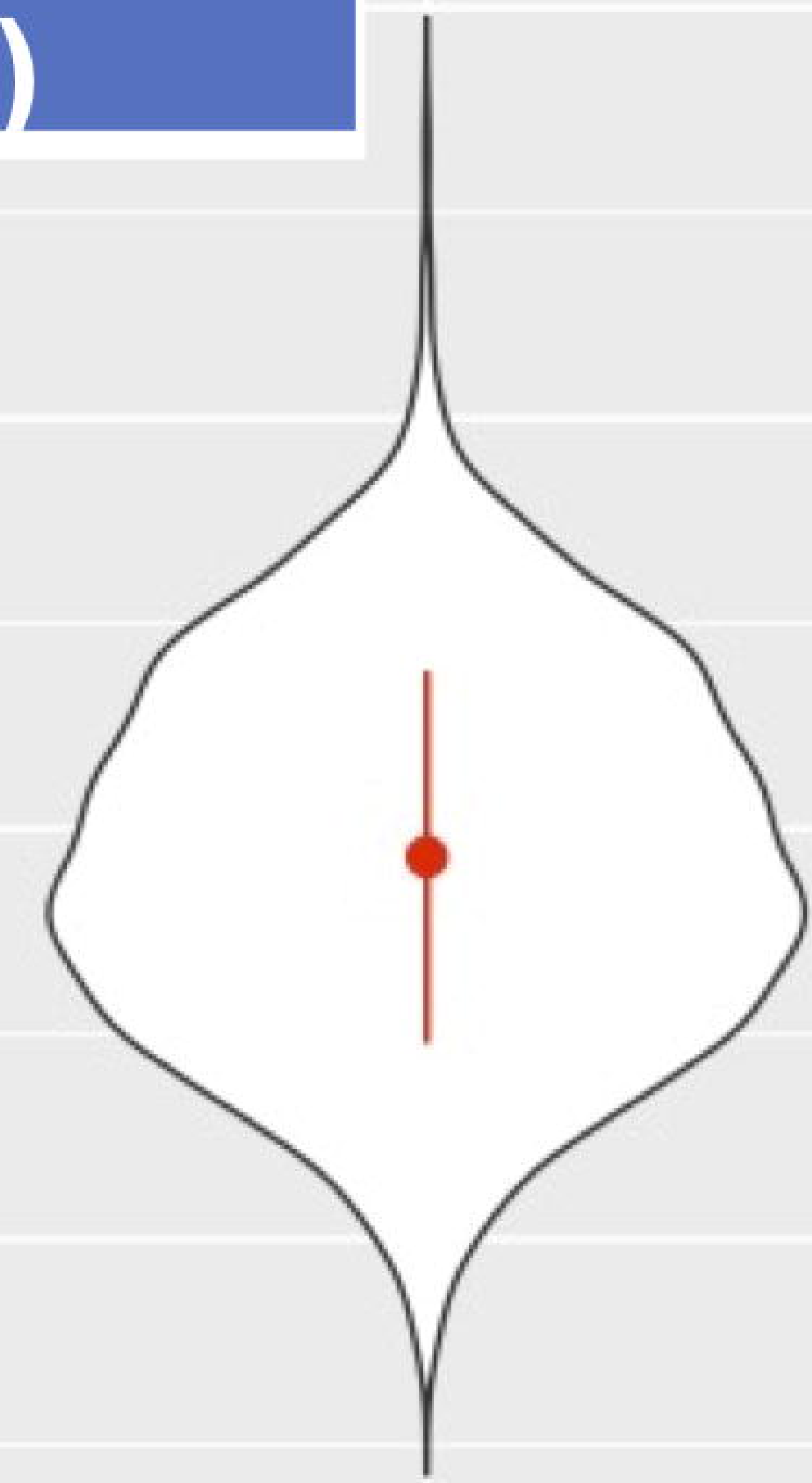

Experimental

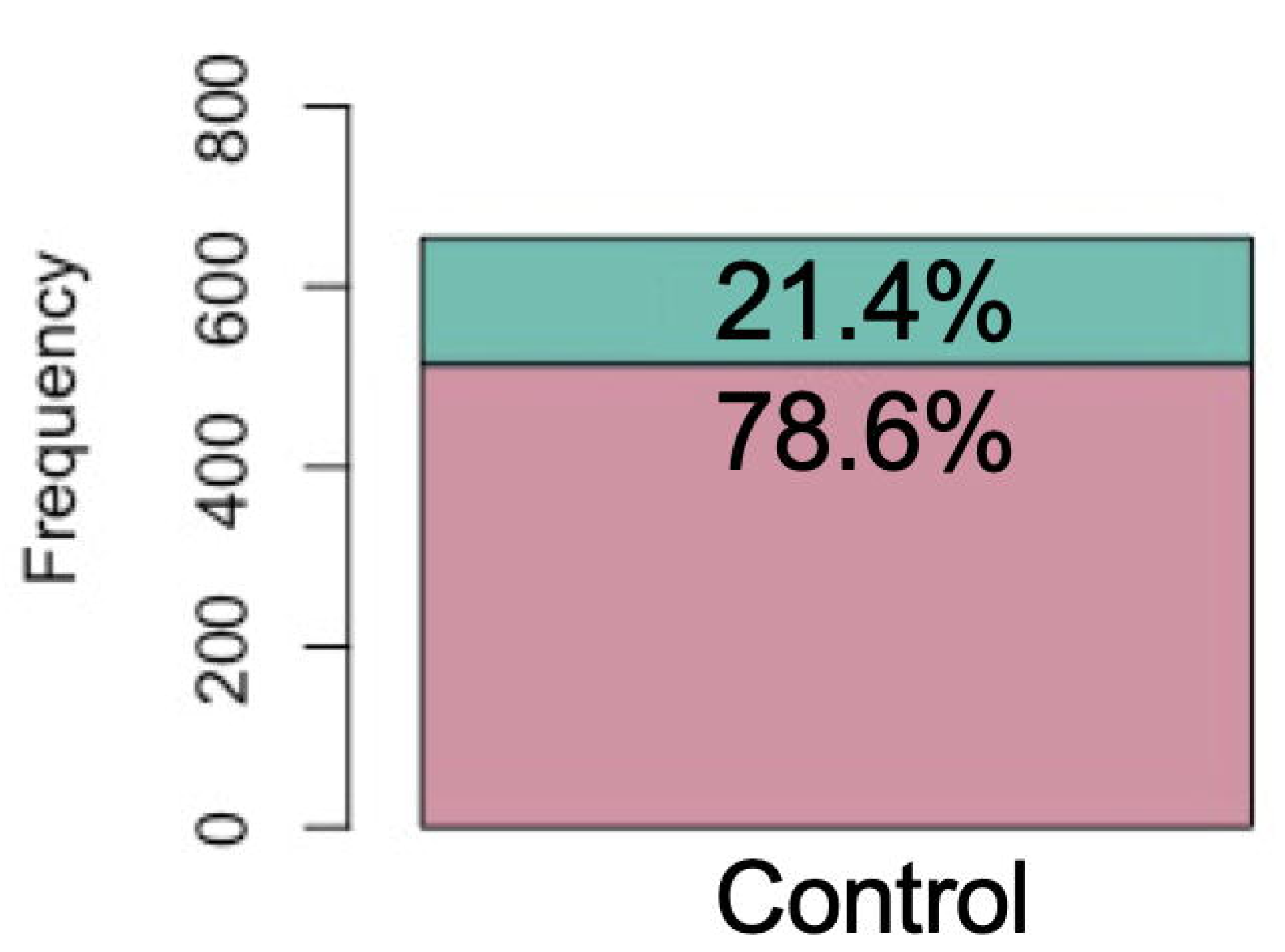

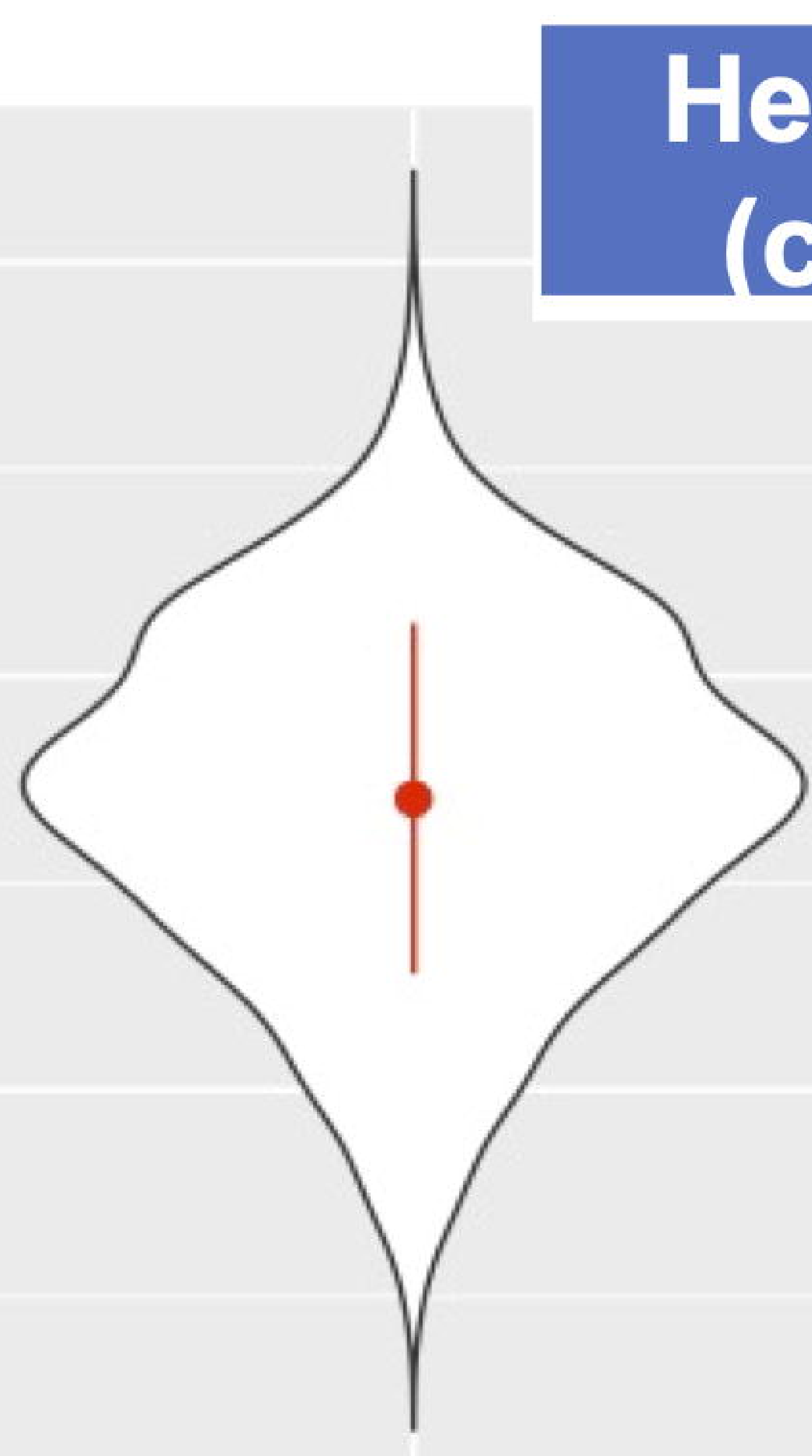

Control

Control
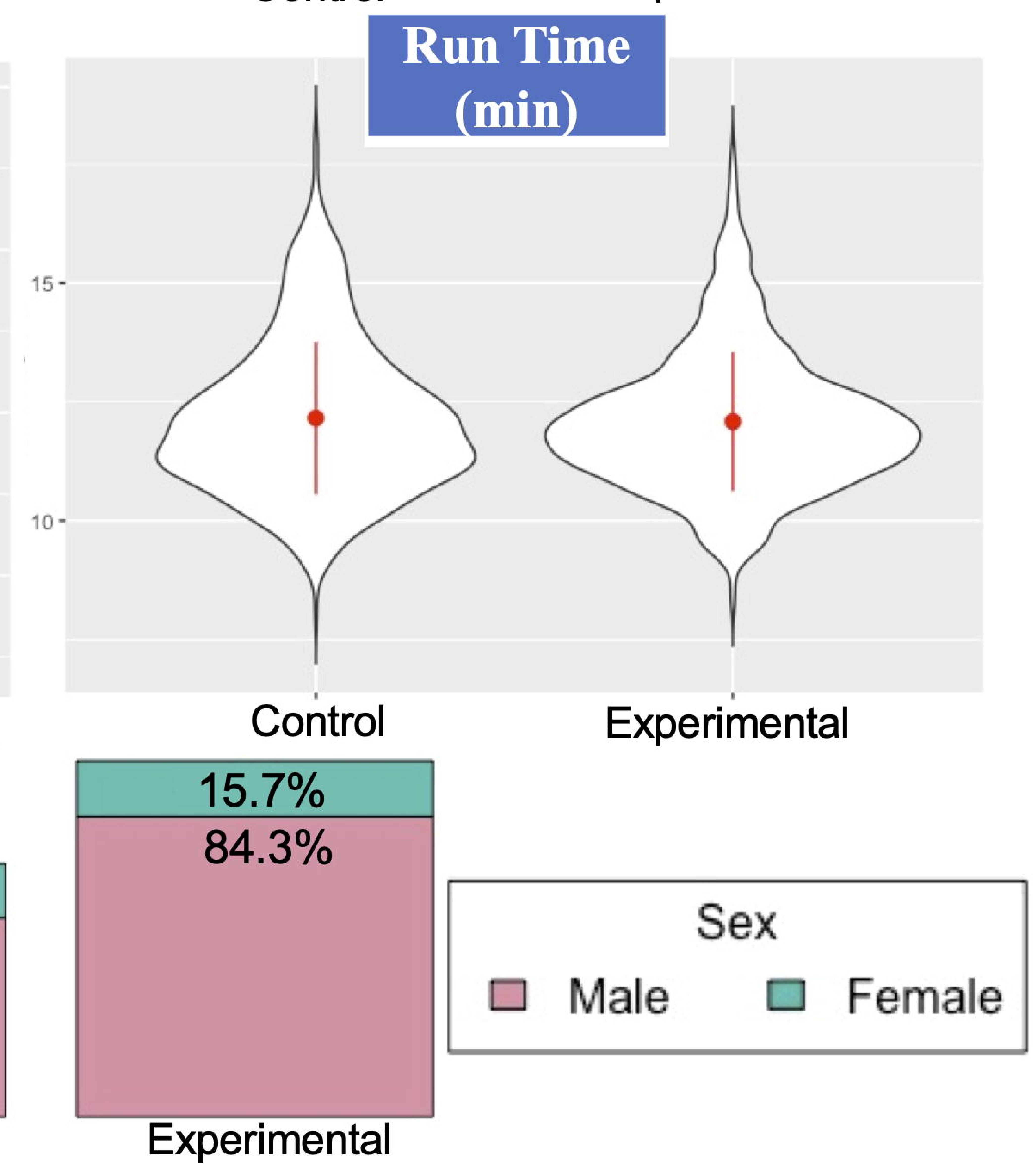

Run Time

(min)

Experimental

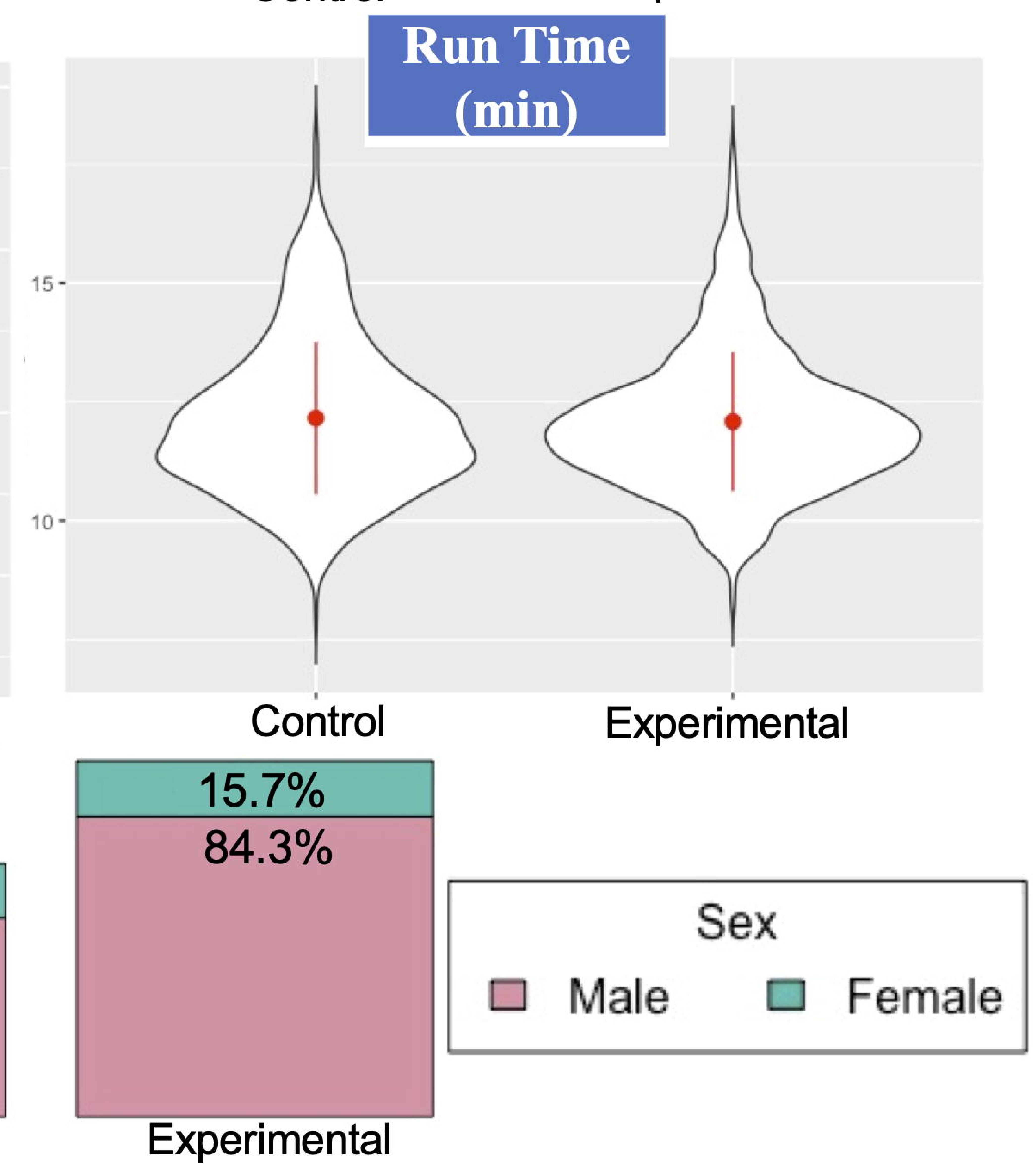

Experimental 


\begin{tabular}{|c|c|c|c|c|c|c|c|c|c|c|}
\hline $\begin{array}{c}\text { Prevalence } \\
\text { (per } 1000 \\
\text { recruits) }\end{array}$ & $\begin{array}{l}\text { Ankle- } \\
\text { Foot }\end{array}$ & Leg & Knee & Thigh & $\begin{array}{l}\text { Lumbo } \\
\text { pelvic-hip }\end{array}$ & RRI & $\begin{array}{c}\text { MTSS \& } \\
\text { Bone Stress } \\
\text { Injuries }\end{array}$ & $\begin{array}{l}\text { Overuse } \\
\text { Injuries }\end{array}$ & $\begin{array}{l}\text { Traumatic } \\
\text { Injuries }\end{array}$ & $\begin{array}{c}\text { All } \\
\text { Injuries }\end{array}$ \\
\hline Experimental & 29.34 & 24.45 & 27.71 & 4.89 & 20.37 & 72.53 & 26.08 & 96.17 & 11.41 & 107.58 \\
\hline Control & 25.59 & 21.15 & 23.88 & 2.73 & 18.08 & 64.14 & 18.76 & 86.32 & 5.46 & 91.78 \\
\hline
\end{tabular}

RRI, Running-related injuries; MTSS, Medial tibial stress syndrome

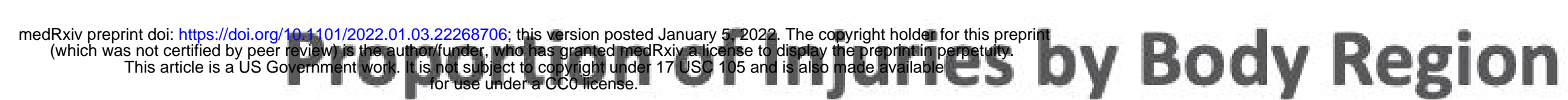

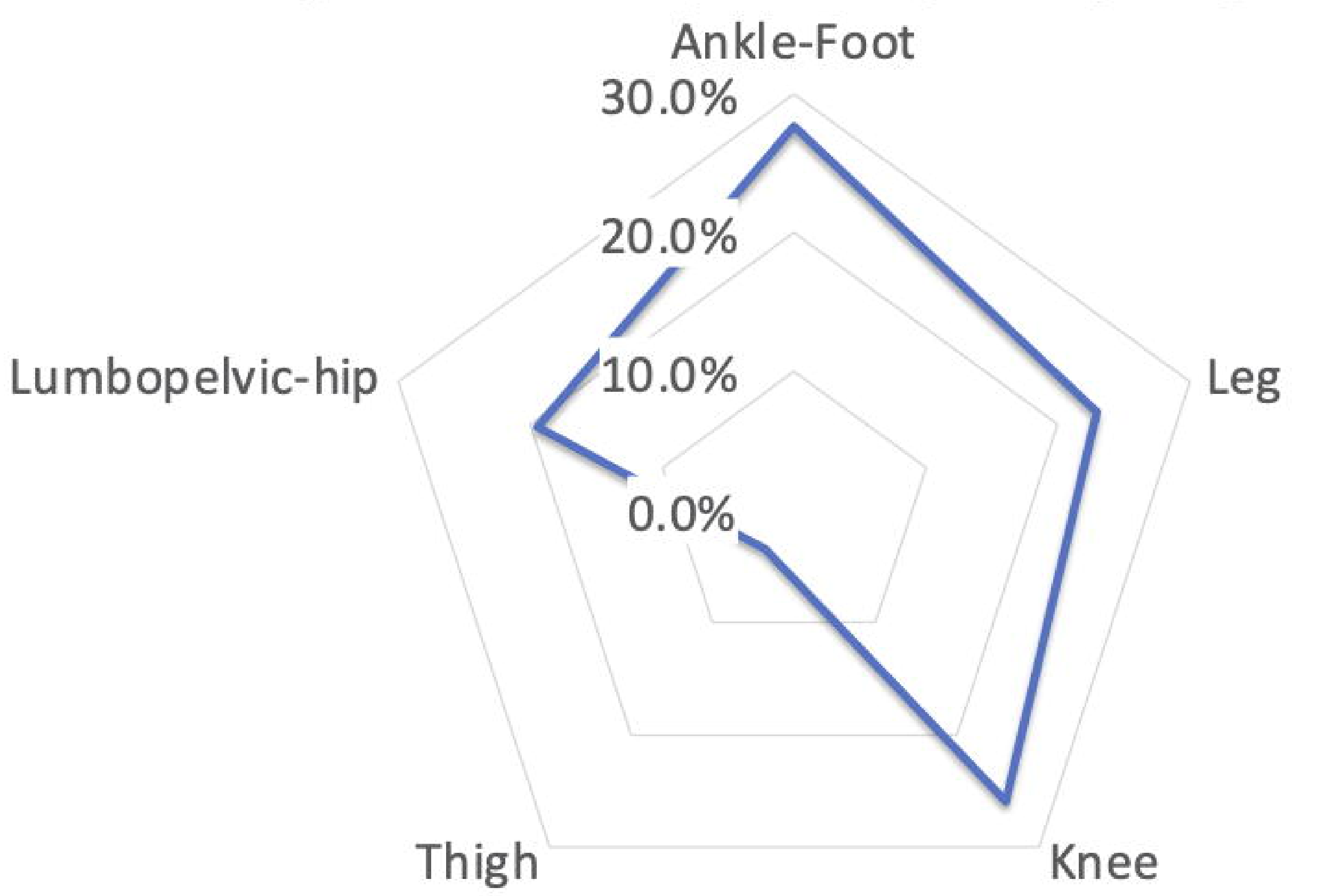

\section{Proportion of Injuries by Type}

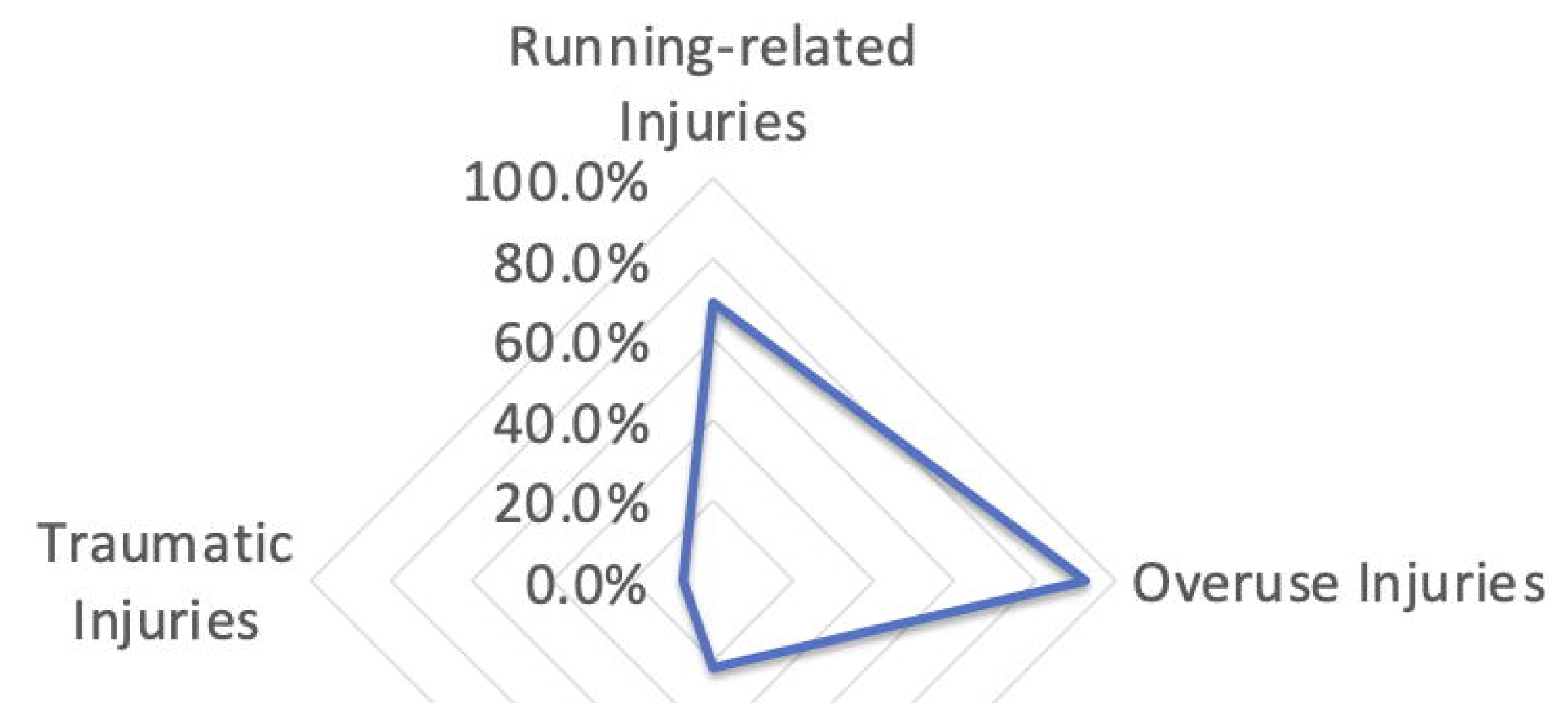

MTSS \& Bone

Stress Injury 